\title{
The Functions of Law and their Challenges: The Differentiated Functionality of International Law
}

\author{
Dana Burchardt*
}

(Received 09 May 2018; accepted 30 May 2018)

\begin{abstract}
This Article illustrates the functional and conceptual variances of law in different contexts. Whereas legal actors on the international level might normatively aim for law to have a similar effect to that of domestic law, the way in which international and supranational law can fulfill these potential functions is different. Accordingly, this Article argues that an awareness of the particularities and challenges that the potential functions of law encounter in the international and supranational context is needed. Moreover, it suggests an analytical lens to conceptually frame and locate current developments, offering a broader perspective on-or even an element of explication for-the apparent crisis that law is currently facing on the international and supranational scale. After describing the potential functions of law on an abstract scale and grouping them into analytical categories, the Article uses these categories as a lens in order to assess in which way international law can fulfill these potential functions, where priorities regarding certain functions might differ, and where some aspects of these functions are challenged when law is made and applied in the international and supranational sphere.
\end{abstract}

\section{A. Introduction}

Understanding what the law is requires an understanding of its functions. ${ }^{1}$ In order to comprehend the nature of law and its mode of operation, the functions that law can potentially and actually fulfill should be taken into account. At the same time, attributing functions to something-including to the law_-endorses a standard by which the success or lack of success of something can be judged. A good functionality of something, that is whether something fulfills its specific function in an optimal manner, reflects its quality. ${ }^{2}$ In this regard, all functionsincluding the functions of law-are evaluative. ${ }^{3}$ Considering the functions of law thus means determining a yardstick for the effectiveness of legal norms and orders.

This approach is particularly relevant with regard to the assessment of international and supranational law. Some have claimed that the functions of law in the international community are the same as the functions of law in any human society; thus, international law should not be considered as something special. ${ }^{4}$ This Article will show that this assessment is only partially true. Even if legal actors on the international level normatively aim for law to have the same effect as it has in a

\footnotetext{
${ }^{*}$ Dr. iur., postdoctoral researcher at Humboldt University Berlin, Berlin Potsdam Research Group "International Rule of Law - Rise or Decline?".

${ }^{1}$ John Finnis, Natural LaW and Natural Rights 6-8 (2d ed. 2011).

${ }^{2}$ ARISTOTLE, Nicomachean ETHICS: Book I.

${ }^{3}$ Andrei Marmor \& Alexander Sarch, The Nature of Law, in The Stanford Encyclopedia of Philosophy ArChive (Edward N. Zalta ed., 2015), https://plato.stanford.edu/archives/fall2015/entries/lawphil-nature/.

${ }^{4}$ Philip Allott, The True Function of Law in the International Community, 5 Ind. J. Glob. Legal Stud. 391,395 (1998). 
domestic context - an "if" that is not always a given —-the way in which international law can fulfill these functions is different. Accordingly, this Article argues that an awareness of the particularities and challenges that the potential functions of law encounter in the international and supranational context is needed.

By way of highlighting these functional and conceptual variances of law in different contexts, the Article suggests an analytical lens to conceptually frame and locate current developments. In particular, it attempts to offer a broader perspective on, or even an element of explication for, the apparent crisis that law is currently facing on the international, supranational, and transnational scale. Some relevant developments include: the stagnation of formal international lawmaking and its replacement by other mechanisms; the questioning of international courts and tribunals; the return of geopolitical power-relations combined with a disregard for existing rules; and the circumvention of lawmaking and treaty-amending procedures by alternative means in order to respond to political, economic, or other crises. These developments, however, are only some of the various phenomena currently posing a challenge to the once highly optimistic conception of international and supranational law.

This Article links the theoretical underpinning of law to these current challenges, offering a function-related viewpoint. With this objective in mind, it follows a two-step analysis. The first part of the Article sets out the standard. It describes the potential functions of law on an abstract scale, grouping them into analytical categories in order to structure the assessment. The second part of the Article applies these functional categories. It uses them as a lens in order to assess in which way international and supranational law can fulfill these potential functions, where priorities regarding certain functions might differ, and where some aspects of these functions are challenged when law is made and applied in the international and supranational sphere.

\section{B. The Potential Functions of Law}

The functions of law are manifold ${ }^{5}$ - as much as the approaches of lawyers in general, and legal theorists in particular, that exist on that issue. ${ }^{6}$ What some consider to be a function of law, others might conceive of as only an (undesired) effect of it. Although there might be many possible diverging definitions, ${ }^{7}$ the term function is conceived of in this Article as follows: The functions of law are defined by its effects, combined with the intentions of the relevant law-creating, lawapplying, and law-assessing actors that law ought to have these effects. ${ }^{8}$ There is no automatic equivalence between effect and function, between is and ought. Thus, the question of what functions law is to fulfill is a highly normative one. The answer to that question is influenced by a wide range of considerations, including the political and cultural background of the observer. Nonetheless, regardless of the normative choice about what law should do within a specific context, there are certain potential functions of law that can be determined. These potential functions relate to the different effects that law can have: On the political powers and the actors exercising these powers; on the social reality of a group; and on the interrelations between individual legal norms. The fact that law is able to have these kinds of effects creates potential functions of law which can materialize into actual functions depending on the normative decision of the norm-creating entities and the social and political actors involved. In this regard, it is important to consider that although every area of law - be it domestic, European or international, criminal or

\footnotetext{
${ }^{5}$ Nonetheless, scholarly discussion often seems to assume the existence of the function of law as a singular aim of legal norms.

${ }^{6}$ See Allott, supra note 4, at 396 (stressing the existence of many competing explanations of law and its functions, as well as the problems following from that).

${ }^{7}$ See Kenneth M. Ehrenberg, The Functions of Law 20-30 (2016) (discussing the different concepts of "function").

${ }^{8}$ See S.R. Perry, Interpretation and Methodology in Legal Theory, in LAW AND INTERPRETATION: ESSAYS IN LEGAL Philosophy 97, 114 (Andrei Marmor ed., 1995) (discussing the link between effects and functions of law); see also EHRENBERG, supra note 7, at 27 (stressing the intentional aspect of these effects).
} 
private, constitutional or administrative - aims to fulfill very different specific functions, they have similar potential abstract functions relating to their legal character.

Against this backdrop, this Article adopts a pluralist understanding of the functions of law. ${ }^{9}$ It therefore includes all potential abstract functions, even if they are incompatible with each other, ${ }^{10}$ or if they seem to be an expression of law's "schizophrenic character." 11 For analytical purposes, the Article will group the potential functions into three categories: The content-related functions; the system-related functions; and the power-related functions. Although these categories are neither logically exclusive nor free of overlaps, they offer a structuring framework to guide the analysis.

\section{Content-Related Functions}

If an emphasis is put on the relationship between law and the social reality it operates in, the first and most inherent function of law comes to mind: Law shapes social reality. In this respect, law is considered as a tool for shaping, framing, and even constructing virtually all areas of human interrelations on the individual and institutional level. This shaping function is at the core of law being a set of norms. All norms - be them legal, moral, religious, or otherwise-inherently contain a normative claim on how reality should look. This claim can be translated into the shaping function of law. Put in temporal terms, law enables a society to shape its future. ${ }^{12}$ From the perspective of social science, one could consider an explicit shaping function to be the main function of all norms; norms are created to solve a social problem. ${ }^{13}$ For some, these social problems arise as a result of social change - thus, law should ultimately be seen as a response to social change. ${ }^{14}$ But even without going that far, law has the potential to broadly influence the substance of social and political relations.

Legal norms have the effect of shaping reality in all phases of their being. In the process of norm-creation, they force political actors to reach a compromise as to what the specific content of a norm should be. In this context, they function as a medium for communicating intentions. ${ }^{15}$ When the existing norm is applied, it frames the behavior of the addressees in a specific way. It singles out a certain possibility among the many possible ways to behave-making it factually harder to choose one of the other possibilities. ${ }^{16}$ Thus, law can contribute to securing desirable behavior and preventing undesirable behavior. ${ }^{17}$ At the same time, it can also contribute to settling disputes. ${ }^{18}$ When an act of non-compliance is sanctioned, it creates a consequence for the lawviolating behavior, a consequence that would not have existed without the legal norm. Additionally, non-compliance leads to an engagement with the norm and forces the addressee into a position to either reach a goal through the norm or despite of the norm. ${ }^{19}$ The reality-shaping function of law can thus be seen as a hybrid of an indirect and direct function of law. The former refers to the application of law and the latter to attitudes and other modes of behavior

\footnotetext{
${ }^{9}$ See Joseph Raz, The Authority of Law: Essays on Law and Morality 167 (1979) (discussing the risk of an analysis of the functions of law that is too closely tied to particular moral or political principles).

${ }^{10}$ See Allott, supra note 4, at 396 (discussing the incompatibility of the competing approaches to the functions of law).

${ }^{11}$ Peer Zumbansen, Transnational Legal Pluralism, 1 Transnat'L Legal TheOrY 141, 154 (2010).

${ }^{12}$ Allott, supra note 4 , at 399.

${ }^{13}$ See Lina Eriksson, Rational Choice Explanations of Norms: What They Can and Cannot Tell Us, in NormS AND VALUES: The Role of Social Norms as Instruments of Value REalisation 179 (Michael Baurmann et al. eds., 2010) (presenting a critical discussion of this approach).

${ }^{14}$ Harry W. Jones, The Creative Power and Function of Law in Historical Perspective, 17 VAND. L. REv. 135, 139 (1963).

${ }^{15}$ EHRENBERG, supra note 7, at 189.

${ }^{16}$ Christoph Möllers, Die MöglichKeIt der Normen: Über eine PraXis Jenseits von Moralität und Kausalität 425 (2015); see also Allott, supra note 4, at 399.

${ }^{17} \mathrm{RAZ}$, supra note 9 , at 169.

${ }^{18} \mathrm{Id}$. at 172; see also Allott, supra note 4, at 405 (stressing the foundations of this function in "tribal law").

${ }^{19}$ MÖLlERS, supra note 16, at 422 (discussing the aspect of norm fidelity (Normtreue)).
} 
which are not obedience to law or its application. ${ }^{20}$ The effect of law singling out specific possibilities and shaping reality in this way can be observed through both direct and indirect implications of legal norms.

Law can also have the function of constructing and securing values. Although, strictly speaking, this function could be included in the shaping function, it has an additional thrust. It can strengthen the respect given to certain moral values. ${ }^{21}$ This goes beyond a narrow understanding of a value-related function of law, which only sees law as implementing the community's values ${ }^{22}$ or expressing them..$^{23}$ In the latter reading, law has a mere executive function. It is seen as taking up pre-existing values and adding a layer of practicality to it. This narrow understanding, however, does not take into account that law can shape, influence, and construct the content of values. It can do this by putting them in a specific legal framework, thereby defining their features, setting limits to them, putting them into a broader context, and relating them to other values. By doing so, law has a normative effect that transcends its execution. Additionally, law also acts as a tool that stabilizes and secures values. Accordingly, law does not limit itself to presupposing independently existing values. Rather, it guarantees the continuity and persistence of the values that are integrated in its legal framework.

For some, this potential value-related function of law translates on the specific social level into a "moral aim of law." ${ }^{24}$ Like other sets of norms, law provides a standard against which human conduct is evaluated; it provides "standards of criticism of such conduct." ${ }^{25}$ In doing so, law creates a yardstick comparable to strictly speaking moral principles, leading to a rapprochement of natural law approaches and positivism. ${ }^{26}$ Some even go further to understand law as aiming not just at criticizing, but also at correcting the moral problems and moral defects of other forms of social ordering. ${ }^{27}$ Such a correctional approach comes with the inherent normative claim that law always induces moral improvement, or even that it always enacts the common interest of society as a whole. ${ }^{28} \mathrm{~A}$ general orientation towards community interests in some legal orders, however, should not be equated with the moral standard that all legal norms always serve a morally good purpose. ${ }^{29}$ Accordingly — and in order to capture a broader variety of approaches-this Article uses the term of law shaping reality.

The potential value-related function of law is the most prominent expression of another, more general function of law, which relates to norms as a stabilizer of expectations. ${ }^{30}$ Norms can lay down expectations in the formal and binding form of law and thus establish a solid basis for expectations and their legitimacy. Human rights provisions are a telling example in this regard. They put expectations regarding political, social, and other guaranties into the legal category of rights. More than just laying down existing expectations, norms can even create and develop new expectations. The normative approach to the value-related function of law can thus be very idealistic. Nonetheless, this of course entails the risk of belying the expectations. Inversely, if law normatively aims at developing realistic expectations, not being too far removed from the existing social reality is a requirement. Also, the legal form makes it more visible when expectations are

\footnotetext{
${ }^{20}$ RAZ, supra note 9, at $167-68$.

${ }^{21} I d$. at $176-77$.

${ }^{22}$ EHRENBERG, supra note 7, at 181 (presenting additional discussion on this understanding).

${ }^{23}$ Cass R. Sunstein, On the Expressive Function of Law, 144 U. PA. L. REV. 2021 (1996).

${ }^{24}$ Ehrenberg, supra note 7, at 184; see also SCOTT J. Shapiro, LEgality 213-17 (2011).

${ }^{25}$ H.L.A. HART, The CONCEPT OF LAW 249 (1961).

${ }^{26}$ EHRENBERG, supra note 7 , at 184 .

${ }^{27}$ SHAPIRO, supra note 24 , at $213-14$.

${ }^{28}$ See Allott, supra note 4, at 399 (claiming the latter point referenced); see also LON L. FulLER, THE MORALITY OF LAW (1964); see also FinNIS, supra note 1, at 276, 335 (stressing law as tool of cooperation in pursuit of the common good of a society).

${ }^{29} \mathrm{RAZ}$, supra note 9, at 158 (discussing the difference between a moral and a legal assessment of law); see also Ronald Dworkin, The Elusive Morality of Law, 10 VILL. L. REV. 631 (1965).

${ }^{30}$ Möllers, supra note 16, at 418; NikLas LuHManN, LAW AS A Social System (2004) 142-72.
} 
belied. ${ }^{31}$ For law in general, this can be especially problematic with regard to expectations created by legal norms themselves. In this case, the specific (social) expectations on a certain subject matter are linked to a general expectation in law as a concept.

\section{System-Related Functions}

Whereas, at least in theory, every individual legal norm can fulfill the described content-related functions, this is not the case concerning the system-related functions of law. The latter arise only from legal norms acting as a group. Although it is a normative question to what extent this is emphasized as a function, the effect of system-creation is inherent to law. It is one of the main effects of the coexistence and interrelation of legal norms. Legal norms both create order ${ }^{32}$ anddifferent from some other sets of (non-legal) norms-depend on order. ${ }^{33}$ As a consequence, it is impossible to understand an individual legal norm without also understanding other legal norms at the same time. ${ }^{34}$ This does not mean that all legal norms would relate to each other, or that the formed order includes all existing norms. Rather, groups of norms create an order to the extent that they are interconnected. They do not necessarily relate in an ordered manner to other groups of norms. Inconsistencies exist. Nonetheless, law is indeed characterized by a multitude of interrelations between legal norms, which cause the interacting legal norms to form a structured entity. In this case, individual legal norms transcend themselves, creating a structure that is more than its elements. At the same time, legal norms and the order that they form enable law to regulate itself-law specifies procedures for making changes to it and regulates bodies to apply it. ${ }^{35}$

The effect of system-creation goes beyond the norms as analytical objects. Law can also be seen as a system of legal relations between legal subjects. ${ }^{36}$ By being subjected to a set of norms, the addressees become interconnected as a normative collective-a group of addressees of legal norms. Consequently, law has an integrative effect. This can become a main function of legal norms when law is understood as enabling certain actors to prove group loyalties and create group identities. ${ }^{37}$ The integrative function is emphasized when law is explicitly used to harmonize legal standards applicable to a group of addressees. Legal harmonization is both a tool to shape reality and a strong element of system-creation, going beyond structures but also orienting content. ${ }^{38}$ Ultimately, norms and the unifying standards set by them can promote social integration. ${ }^{39}$

Yet creating a collective is not only an effect and potential function of specific legal norms. Indeed, law as a concept also presupposes a collectivization of the addressees with regard to their trust in this very concept. ${ }^{40}$ Law presupposes the trust or belief of every addressee that every other addressee trusts or believes in law. Law is a common idea which can materialize only if the idea is shared by everybody. On this basis, law functions as a conceptual unifier.

With law, as with any system, comes an additional social function. Many theorists are of the view that the function of law is to organize behavior and provide guides to human

\footnotetext{
${ }^{31}$ Möllers, supra note 16 , at 419.

${ }^{32}$ Edward Jenks, The Functions of Law in Society, 5 J. COMP. LEGIS. \& INT'L L. 169, 170 (1923) (understanding order to be one of the two elements implied by law).

${ }^{33}$ MölleRs, supra note 16 , at 179.

${ }^{34}$ Möllers, supra note 16 , at 181.

${ }^{35} \mathrm{RAZ}$, supra note 9, at 175 (calling these two aspects-regulating law-creation and law application-the secondary functions of law). According to this terminology, the secondary function of instituting law-applying bodies serves to regulate and solve disputes.

${ }^{36}$ Allott, supra note 4 , at 400 .

${ }^{37}$ Eriksson, supra note 13, at 185 (referring to this concept as the signaling function of norms).

${ }^{38}$ Manfred Zuleeg, Die Europäische Gemeinschaft als Rechtsgemeinschaft, 1994 NeUE JURISTICHE WOCHENSCHRIFT 545 (1994) (using the term "unifying tie of law" (einigendes Band des Rechts)).

${ }^{39}$ MÖLlERS, supra note 16 , at 418

${ }^{40}$ See Jan Ruzicka \& Vincent Charles Keating, Going Global: Trust Research and International Relations, 5 J. TR. RES. 8 (2015) (discussing trust in international relations).
} 
conduct. ${ }^{41}$ This enables society or group members to cooperate and solve coordination problems. ${ }^{42}$ A key aspect of the system-related function of law is thus to create social order by providing a guiding structure for individual and collective actors. ${ }^{43}$ This could also be referred to as a coordinative function of law. ${ }^{44}$ With the coordination of individual behavior comes the structuring of society as a system. When law structures society as a system, it fulfills a function of system-creation on the social level. This complements the above-mentioned system-creation on the level of the legal norms.

Another aspect of the potential system-related functions of law links law to politics. Law can have, and can be given, the effect of constitutionalization - understood as a system-creation on the political level. Within the framework of the functions of law, the term constitutionalization as it is used here describes the fact that a political entity is based on, and depends upon, law. As a result, the entity is considered first and foremost to be a legal construction and is only secondarily considered a political construction. Whereas this is debatable for the political entity of a State, it can be witnessed, by way of example, in the form of the European Union. The EU has been mainly perceived as a creation of law, with its legal nature dominating its political (and economic) aspects. ${ }^{45}$ That law is capable of this far-reaching effect is due to the combination of the extensive powerrelated, content-related, and system-related functions that law can have. They cause law to be "the quintessential institution for creating other institutions." ${ }^{\prime 6}$ This mirrors the institutional nature of law. ${ }^{47}$

\section{Power-Related Functions}

The power-related functions look at the relationship between law and politics from two opposing sides, taking into account that law and politics can be "either in agreement or in opposition." 48 The first perspective in this regard concerns the restriction of power. The power-limiting function of law is one of its most normative functions. Law can set limits to actions of the State and of the individuals belonging to a society; it can set limits to politics. ${ }^{49}$ In particular, law in its public dimension channels and organizes power. ${ }^{50}$ In doing so, law restrains contingency and creates certainty. The exercise of powers becomes predictable in so far as actors have to abide by the limits set by law. These limits are of both a procedural and substantive nature. Law gives a procedural framework to the way power is exercised and at the same time, it determines the result of this exercise in terms of content. The rule of law discussion both on the national and international

\footnotetext{
${ }^{41}$ See HART, supra note 25, at 249; see also Jenks, supra note 32, at 171; see also HANs Kelsen, The Pure TheORY OF LAW 31 (Max Knight trans., Univ. Cal. Press 1967); see also Lon L. Fuller, Human Interaction and the Law, 14 AM J. JURIs. 1, 23 (1969); see also Anton-Hermann Chroust, The Managerial Function of Law, 34 Bos. UnIV. L. Rev. 261 (1954).

${ }^{42}$ FinNis, supra note 1 , at 153, 245.

${ }^{43}$ Jenks, supra note 32, at 173; see also Lon L. Fuller, A Reply to Professors Cohen and Dworkin, 10 VILL. L. REV. 655, 657 (1965) (“[A] system directing human conduct by rules . . ."); RAZ, supra note 9, at 169-70. These guiding structures can include, for example, legal facilities and frameworks for private arrangements between individuals.

${ }^{44}$ Ehrenberg, supra note 7, at 183; see, e.g., Gerald J. Postema, Coordination and Convention at the Foundations of Law, 11 J. LEgal STUD. 165, 183 (1982). Some, however, point out that instead of solving problems, law can also maintain, or even create, them in the first place.

${ }^{45}$ See Allott, supra note 4, at 392 (providing an additional example: some see the transformation of the American colonies into a new kind of society at the end of the eighteenth century as an achievement of law).

${ }^{46}$ EHRENBERG, supra note 7, at 190.

${ }^{47}$ RAZ, supra note 9 , at $103-21$.

${ }^{48}$ Miro Cerar, The Relationship Between Law and Politics, 15 ANN. Surv. Of INT'L \& Comp. L. 19, 22 (2009).

${ }^{49} \mathrm{See}$ id. at 37 (presenting law, from the perspective of power, law as an "obstacle on the way toward the realization of certain political goals"); see also Frank Schorkopf, Gestaltung mit Recht: Prägekraft und Selbststand des Rechts in einer Rechtsgemeinschaft, 136 ARCHIV Des ÖFFENTLICHES ReCHT 323 (2011) (discussing the power-limiting function).

${ }^{50}$ Benedict Kingsbury, The Concept of "Law" in Global Administrative Law, 20 EUR. J. INT'L L. 23, 32 (2009).
} 
level is closely related to this function, ${ }^{51}$ as well as the idea of constitution and constitutionalism. ${ }^{52}$ If the rule of law is understood in the sense of jurisdictio-as opposed to law as gubernaculum ${ }^{53}$ it requires that law should always be controlled by other law, and that political power should always be bound by clear legal norms which are outside of the reach of the political. ${ }^{54}$ In this regard, providing certainty and predictability of the exercise of political power and of its intrusion into the sphere of the individual are important elements of this power-limiting function of law. ${ }^{55}$ Also, even if one does not agree that law should allow "predicting official behaviour," the function of law can nonetheless be seen as providing "a standard of criticism of behaviour, including the behaviour of officials." 56

This can be supplemented by a normative dimension that is related to the aspect of legitimization. For some, the function of law is to justify the State's use or withholding of force. ${ }^{57}$ This can even be stretched further by declaring this function to be law's defining feature: Anything that does not perform this justificatory function cannot be counted as law. ${ }^{58}$ This approach shifts the understanding of law as a tool for restraining power to law being the source of legitimacy for any exercise of power. This fundamentally effects the perception of the relationship between law and power, insofar as both approaches differ with regard to the primary point of referencelaw or power. The orientation of both approaches, however, remains the same: Being the source of legitimacy for the exercise of power represents the ultimate restriction of power.

In fact, it is not only the power of the State or of other institutional organizations that can be regulated and limited by law. A further dimension of limitation is situated on the individual level. Law has been described as "attempt to prevent the individual encroaching on the interests of his fellows ...." In Individuals and their freedom (e.g. their freedom of contract) are subjected to legal restrictions which are linked to the benefits coming with the provided legal framework. ${ }^{60}$ This amounts to limiting the original powers within a society before they have been institutionalized. Of course, this variation of the power-limiting function which concerns the individual is closely related to the institutionalization of power in the form of a State. In this context, an important potential function of law is to make the use of force a monopoly of the community. ${ }^{61}$ This highlights graphically how the relations within the triad individual-State-law is often perceived: ${ }^{62}$ In order to limit the power relations between individuals, power is institutionalized in the form of the State and is exercised by the State through law. ${ }^{63}$

\footnotetext{
${ }^{51}$ See Robert McCorquodale, Defining the International Rule of Law: Defying Gravity?, 65 INT'L \& CoMP. L. Q. 277 (2016) (providing a general overview of the discussion on the international rule of law).

${ }^{52}$ See Wouter Werner, The Never-Ending Closure: Constitutionalism and International Law, in TRANSNATIONAL Constitutionalism: International and European Perspectives 329, 330 (Nicholas Tsagourias ed., 2007) (discussing constitutionalism aiming for a "legal control of politics").

${ }^{53}$ Gianluigi Palombella, The Rule of Law as an Institutional Ideal, in RUlE OF LAW AND DEMOCRACY: INQUIRIES INTO Internal AND EXternal Issues 1 (Leonardo Morlino \& Gianluigi Palombella eds., 2010).

${ }^{54}$ Dimitry Kochenov, EU Law without the Rule of Law: Is the Veneration of Autonomy Worth It?, 34 Y.B. EUR. L. 74, 75, 82 (2015); Palombella, supra note 53, at 24, 27-30.

${ }^{55}$ Richard S. Kay, Judicial Policy-Making and the Peculiar Function of Law, 26 UnIV. QueENSL. L.J. 237, 251 (2007) (stressing this aspect).

${ }^{56}$ Martti Koskenniemi, The Mystery of Legal Obligation, 3 InT'L THEORY 319 (2011).

${ }^{57}$ Ronald DWORKIN, LAw's EMPIRE 93 (1986); see also EHRENBERG, supra note 7, at 55-68 (presenting a recent discussion of this approach).

${ }^{58}$ See EHRENBERG, supra note 7, at 180 (discussing this aspect).

${ }^{59}$ Jenks, supra note 32 at 171.

${ }^{60} \mathrm{RAZ}$, supra note 9 , at 171 .

${ }^{61}$ Hans Kelsen, General Theory of Law And State 21 (Anders Wedberg trans., Lawbook Exch. 2011).

${ }^{62}$ This is irrespective of the debated question whether law requires a coercive aspect to be called law. See KELSEN, supra note 41 , at 33 (considering it to be a requirement that the law have a coercive aspect); HART, supra note 25, at 20-25 (denying that law requires a coercive aspect to be called law and understanding the coercive aspect of law to be marginal).

${ }^{63}$ See Jenks, supra note 32, at 175 (describing law as "a rule of conduct enforced by the State").
} 
Contrary to an understanding that sees law primarily as a limitation to power in its various forms, the reverse understanding is possible as well. Indeed, law can also be conceived of as a tool to exercise power-and not to restrain it. This perspective on the relationship between law and politics might actually be a historically older and more conventional function of law. Over time, it has found a broad variety of forms, including law being a means of economic exploitation and colonization ${ }^{64}$ or an instrument of the State and of "class struggle" in the perception of communist States. ${ }^{65}$ The numerous examples further include the influence of lobbyists on legislative procedures, or the contractual inequality in consumer/business contracts. What is more, law can also be used as a tool to mask the exercise of power. The reason for this is that the idea of juridification of human interrelations comes with a claim of independence of the law, a (formal) decoupling from the political. Hence, law can be at the same time the means for and the disguise of power. ${ }^{66}$

Although the potential function of exercising power seems diametrically opposed to the powerlimiting function of law, both functions are actually able to coexist-each in a moderate form. Nevertheless, this requires an equally "moderate" understanding of the relationship between law and politics that does not see politics as internal to law in the sense of "law is politics." 67 If one takes a two-pronged approach, the relationship could be described as follows: It is immanent to law that law is the means of politics in view of its creation and design; ${ }^{68}$ yet, at least conceptually, law is or ought to be independent from politics once the law has been created. ${ }^{69}$ Put differently, law and politics are "structurally coupled systems. Law is the product of political activity which has been fixed in order to organize. .. political action." ${ }^{70}$ In its moderate form, the relationship between law and politics is such that particular interests never fully determine the outcome of the lawmaking. Under this premise, a power-limiting and a power-exercising function of law can be combined.

\section{The Differentiated Functionality of International Law}

The discussion of the potential functions of law has shown the possibilities for law to serve various purposes. To what extent the individual functions can be implemented depends, however, on the political and social context. In particular, it can be challenging for some of the potential functions when law is situated outside of the institutional and conceptual limits of the State. This Section will show that the differentiated functionality of law can be better understood using the categories of functions developed above.

\section{Challenges to the Content-Related Functions}

For the international and supranational legal sphere, the content related functions of law have been most crucial. The idea of shaping reality through law is at the core of both supranational and-to a less explicit extent-international legal developments. The narrative of integration through law has been the essence of European integration for decades. ${ }^{71}$ Supranationally, law

\footnotetext{
${ }^{64}$ See Simon Chesterman, Asia's Ambivalence About International Law and Institutions: Past, Present, and Futures, 27 EUR. J. INT'L L. 945, 947-50 (2016).

${ }^{65}$ Hungdah Chiu, Communist China's Attitude Towards International Law, 60 AM. J. INT'L L. 245, $246-49$ (1966).

${ }^{66}$ See, e.g., R.A. Mullerson, Sources of International Law: New Tendencies in Soviet Thinking, 83 AM. J. INT'L L. 494 (1989) (discussing the critique of these influences on international law by classical Marxist approaches).

${ }^{67}$ Mark Tushnet, Critical Legal Studies: A Political History, 100 Yale L.J. 1515, 1517 (1991).

${ }^{68}$ Philip Allott, The Health of Nations: Society and Law Beyond the State 309 (2002) (describing law-making processes as a "by-product of politics").

${ }^{69}$ See Cerar, supra note 48 , at 22-23.

${ }^{70}$ Anne Peters, Compensatory Constitutionalism: The Function and Potential of Fundamental International Norms and Structures, 19 LEIDEN J. INT'L L. 579, 609 (2006).

${ }^{71} 1$ Integration Through Law: Europe and the American Federal Experience (Mauro Cappelletti et al. eds., 1986).
} 
has been given an integrative and shaping function that goes beyond the function of law in many domestic legal orders. The idea of integration through law is also at the origin of the powerful position of European courts. ${ }^{72}$

Whereas internationally this narrative has never been as explicit as for European law, there has nonetheless been a strong legalization of international relations, especially since the early 1990 s. $^{73}$ Analogous to the European terminology, one could speak about internationalization through law - or even globalization through law - to capture this development (a development that qualitatively and quantitatively goes further than the narrative of "peace through law" that emerged more than a century ago). Law has been seen by many as "the best way to make a better world. ..."74 Although international law differs from European law with regard to the level of integration, the prominent role of law is comparable. As a consequence, the expectations in law of the relevant law-creating and law-applying actors and of the addressees are also comparable. This is additionally reflected in the equally prominent role of international courts, giving effect to these expectations. ${ }^{75}$ Conceptually, certain readings of the development of international law, for instance the concept of global constitutionalism, ${ }^{76}$ express particularly high expectations in the shaping function of international law. More generally, liberal internationalism as a basic approach has been described as reflecting an idealistic vision of what international law can achieve in terms of shaping reality. ${ }^{77}$

The shaping function of law is probably the most inherent function, not only of legal norms, but also of norms in general, although their shaping effect can differ. As a result of this inherent character, the different kinds of norms existing within the international legal space fulfill this function. This includes both hard legal norms as well as norms belonging to the category of soft law. In particular, norms can shape reality by singling out one possibility-which makes realizing other possibilities harder. To show this effect, norms do not need to be hard legal norms with binding obligations. The standards constructed by soft law are sufficient to factually shape the reality of possibilities. ${ }^{78}$ In this regard, it can remain open whether soft law standards are qualified as formally recognized legal norms. Being a form of norms tout court, they are in any event able to fulfill the shaping function of norms. Additionally, they can, when fleshing out existing hard law norms, perpetuate the shaping effect of these legal norms.

There are two particularities in the shaping function of international law. First, whereas international law can fulfill a shaping function and have a shaping effect during the processes of law-creation and law-application, this is the case to a lesser extent for the process of enforcement. The enforcement structure on the international level removes at least partially one of the three phases available to law for reality-shaping. International courts and tribunals, as well as the UN Security Council — though to a factually limited extent due to the frequent use of the veto-are the only active mechanisms of enforcement available. Because of this, a significant proportion of the enforcement phase is taken over either by political means used by international actors, or by non-international actors (e.g. domestic courts). Second, the social dimension of the shaping function of both hard and soft international norms, which relates to guiding and structuring human

\footnotetext{
${ }^{72}$ For domestic courts, this is primarily based on the possibility of a preliminary ruling procedure.

${ }^{73}$ See Karen Alter, The New Terrain of International Law: Courts, Politics, Rights (2014) (discussing the role of international court in this development).

${ }^{74}$ Allott, supra note 4 , at 413 .

${ }^{75}$ Alter, supra note 73.

${ }^{76}$ See, e.g., Anne Peters, Global Constitutionalism, in The Encyclopedia of Political Thought 1484 (Michael Gibbons et al. eds., 2014); see also JAn Klabbers ET AL., The Constitutionalization of InTERnational LaW (2009); RULING THE World?: COnstitutionalism, InTERnational LaW, and Global Governance (Jeffrey L. Dunoff \& Joel P. Trachtman eds., 2009).

${ }^{77}$ See Daniel Joyce, Liberal Internationalism, in OXford HANDBOOK OF THE THEORY OF INTERNATIONAL LAW 471, 478 (Anne Orford \& Florian Hoffmann eds., 2016) (discussing the critique of this idealism).

${ }^{78}$ MÖLlERS, supra note 16 , at 425 .
} 
behavior, is partially mediated. The underlying substructure of human behavior addressed by international law is often not directly the behavior of human beings but the behavior of governments acting on behalf of States. ${ }^{79}$ Due to the involved group decision-making processes, this mediated link between norm and behavior can complicates the mode of action of reality-shaping. Additionally, mediated and immediate shaping effects coexist. This is, for instance, the case when State-related international law and transnational law aim at shaping similar areas of human behavior.

The potential function of constructing and securing values has also been important for the international legal sphere. Values, although always present in lawmaking, can be accentuated or downplayed. Constructing and securing values becomes an explicit normative function when norms are openly designed not as technical rules, but as legal translations of certain fundamental values. In the previous decades, international law has arguably seen a shift from a system based mostly on State-oriented principles towards a more value-based order, emphasizing the rights of individual persons. ${ }^{80}$ Yet this development has come with a risk, especially when values are given a universal effect. It can affect a society negatively if moral norms and values are represented as universal and absolute; it undermines the differentiated nature of the society. ${ }^{81}$ As a result, when the existing substantive value-diversity is stressed by international actors, this not only undermines the claim about the universality of substantive standards such as international human rights, but also questions the function of constructing and securing values at the international scale altogether. ${ }^{82}$ This tendency is reflected in the criticism against international law of promoting western values, human rights imperialism, and general hegemonic tendencies by the western world. ${ }^{83}$ It has also triggered alternative readings of the existing law, as well as the creation of alternative sets of rules and regimes. ${ }^{84}$

More generally, it can become problematic when the shaping function of law is approached in an idealistic way. High expectations in the shaping capacity of law can turn out to be excessive. Wherever these expectations are not met, the trust in law as a concept is negatively affected. This concerns specific aspects of law with specific purposes, such as financial stability in European law, or the use of force in international law. Moreover, it affects law in its entirety. If the trust in law's ability to shape one particular field is compromised, the overall trust in its ability to shape other fields indirectly is compromised as well.

On the supranational level, the expectations in the shaping function of law have been extraordinarily high. The narrative of integration through law has given jurists the prerogative of interpretation for the process of European integration. The manifold crises in the European legal space- the financial crisis, the migration crisis, and the crisis of domestic rule of law standards, among others - have made obvious, however, that law alone cannot always effectively regulate all areas of human behavior. On several occasions, politics needed to find answers without being

\footnotetext{
${ }^{79}$ Allott, supra note 4 , at 404.

${ }^{80}$ See, e.g., G.A. Res. 60/1, 2005 World Summit Outcome (Sept. 16, 2005); see also Theodor Meron, The Humanization OF INTERNATIONAL LAW (2006).

${ }^{81}$ Niklas Luhmann, Paradigm Lost: On the Ethical Reflection of Morality, 29 THESIS ELEVEN 82, 86 (1991).

${ }^{82}$ Matej Avbelj, Transnational law Between Modernity and Post-modernity, 7 Transnat'l Legal TheORY 406, 425 (2017).

${ }^{83}$ See, e.g., Ilias Bantekas \& Lutz Oette, International Human Rights LaW and Practice 27 (2d ed. 2016) (discussing this challenge for Human Rights); M. Cherif Bassiouni, Universal Jurisdiction for International Crimes: Historical Perspectives and Contemporary Practice, 42 VA. J. INT'L L. 81, 155 (2001) (discussing hegemonic tendencies in international criminal law). See also Martti Koskenniemi, The Gentle Civilizer of Nations (2001) (presenting a historical account);

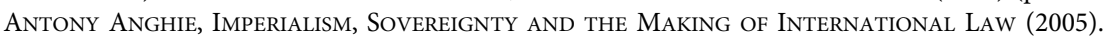

${ }^{84}$ See, e.g., Li-ann Thio, Implementing Human Rights in ASEAN Countries: "Promises to Keep and Miles to Go Before I Sleep", 2 Yale Hum. RTs. \& Dev. L.J. 1 (1999) (discussing the challenge of western human rights by Asian values); see also David P. Fidler, Eastphalia Emerging?: Asia, International Law, and Global Governance, 17 IND. J. GLOB. LEGAL STUD. 1, 3 (2010) (discussing a concept of 'Eastphalia' in contrast to 'Westphalia' reflecting Asian power structures and principles); Chesterman, supra note 64, at 972 (discussing the creation of the Asian Infrastructure Investment Bank as an alternative regime to the Bretton Woods institutions).
} 
guided by law. In the recent past, this often happened on an ad hoc basis and outside of the supranational legal structures. ${ }^{85}$ European law-and to some extent law in general—is perceived to have disappointed in times of crisis with regard to the effectiveness of its shaping function. Consequently, one can arguably witness a loss of trust. ${ }^{86}$ This loss of trust in law, and in its shaping function, has had a severe impact due to the fact that legal integration is the basis of the entire political construction. ${ }^{87}$ The narrative of the EU as a "community of law" 88 is fundamentally challenged.

On the international level, high expectations in the shaping function of law have been present, although probably not to the same extent as on the supranational level. In the international sphere, the predominance of politics is much too incorporated in the idea of international relations to have given law the same creative leeway and guiding role as it has happened in the context of European integration. Nonetheless, the perception that international law can successfully shape the major aspects of international and transnational relations has become predominant for a certain period of time, at least from a western perspective on international law. The legalization and considerable multiplication of international treaties in the post-cold-war period bear witness to that. These high expectations have been challenged by recent developments. Conceptual and factual shifts can be seen both as a cause and a symptom of expectations that are perceived to be either disappointed or overplayed. The various examples include: the unilateral use of force in the context of Ukraine or Syria; certain international courts being increasingly criticized by member States, and even faced with withdrawals; and the rise of populist politics that are critical of international law. This has arguably led not only to stagnation in international lawmaking, ${ }^{89} \mathrm{but}$ maybe even to a crisis of international law in general. ${ }^{90}$

Nonetheless, this analysis of how high expectations in the potential shaping function of international law first developed and have later been challenged, does not reflect a comprehensive global view on the issue. From the perspective of many Asian States, the expectations of what law and especially international law can do, and how it can shape reality, have been significantly lower. ${ }^{91}$ This is reflected in an under-participation and under-representation of many Asian States in international law regimes, as "[c]olonialism, the unequal treaties, and the post-war experience encouraged the perception that international law is of questionable legitimacy, can be used for instrumental purposes and is necessarily selective in its application." 92 Thus, the expectations of non-western States are often not only lower, but also different. There are, for instance, different views on which particular power relations and the position of which actors should be reflected by

\footnotetext{
${ }^{85}$ See generally, Christopher Schoenfleisch, Integration Durch KoOrdinierung? (2018) (discussing the impact of the so-called intergovernmental method replacing supranational regulation).

${ }^{86}$ Armin von Bogdandy, Jenseits der Rechtsgemeinschaft: Begriffsarbeit in der Europäischen Sinn-und Rechtsstaatlichkeitskrise, 52 EUROPARECHT 487 (2017) (discussing the crisis of trust).

${ }^{87}$ See Armin von Bogdandy, European Law Beyond “Ever Closer Union" Repositioning the Concept, its Thrust and the EJC's Comparative Methodology, 22 EuR. L.J. 519, 527-28 (2016) (discussing the need to emancipate European unity from integration).

${ }^{88}$ This goes back to Walter Hallstein, Die EWG - Eine Rechtsgemeinschaft, in EuROPÄISCHE REDEN 341 (Thomas Oppermann ed., 1979). See also ECJ, Case 294/83, Les Verts v European Parliament, ECLI:EU:C:1986:166, Judgement of 23 April 1986, at 23 (referring to the concept of a "community based on the rule of law" for the first time).

${ }^{89}$ Joost Pauwelyn et al., When Structures Become Shackles: Stagnation and Dynamics in International Law Making, 25 EUR. J. INT'L L. 733 (2014).

${ }^{90}$ Heike Krieger \& Georg Nolte, The International Rule of Law-Rise or Decline? Points of Departure, in THE INTERNATIONAL Rule of Law - Rise or Decline? - Approaching Current Foundational Challenges (Heike Krieger et al. eds., forthcoming).

${ }^{91}$ See, e.g., B.S. Chimni, International Law Scholarship in Post-Colonial India: Coping with Dualism, 23 LEIDEN J. INT'L L. 23 , 42-45 (2010) (discussing India's disillusionment with the capacity of law to change the international economic order).

${ }^{92}$ Chesterman, supra note 64, at 964; see also Dong WANG, China's Unequal Treaties: NarRating National History (2005) (discussing unequal treaties).
} 
international law. ${ }^{93}$ Moreover, whereas States with strong and independent courts might have high expectations in law and consider law to be self-standing with regard to the political sphere, other States traditionally might conceive of law as more densely intertwined with, and an instrument of, politics. ${ }^{94}$ Such internal approaches to law might be translated to the international level, although this does not have to be the case. On the global scale, such diverging expectations of the various international actors about what law can and should achieve can be problematic in itself. This is exemplified by the disagreement over whether and to what extent international law should be value-based.

For international law, another aspect can influence how far-reaching the shaping effect of international law can be. The international legal order is characterized by a strong interlinkage between the law-creating, law-applying, and law-enforcing actors. Despite the multiplication of actors, including non-State actors, international law is still to a considerable extent horizontal law. This is the case wherever there is identity of the makers and the subjects of the law - as well as of those who have the supreme authority of interpreting the law. ${ }^{95}$ This leads to a predominance of unanimous lawmaking procedures which, in contrast to majoritarian systems, may often allow only for less ambitious regulations. Fulfilling a shaping function thus is difficult for law when the interests of the actors are perceived as increasingly divergent and when certain actors are in stronger positions to assert their interest. For instance, the emergence of "new powers" such as India, China, or Brazil creates new divisions and makes consent-finding more difficult. ${ }^{96}$ Tendencies towards a regionalization of international law can be understood as one of the fall back options for international actors in order to shift the shaping function to a different level. ${ }^{97}$ In this context, territorial limitation appears to be the trade-off for upholding a broader substantive shaping function by international law.

Another result of the strong interlinkage between the law-creating, law-applying, and lawenforcing actors is that many (hard) international legal norms are-once they are created-fairly inflexible. ${ }^{98}$ Despite the possibility of developing existing provisions through their interpretation and thereby accounting for subsequent practice, a modification or development of the existing international law is often difficult when compared to the legislative flexibility of other legal orders. ${ }^{99}$ Classical international law has always been relatively static. ${ }^{100}$ Consequently, it can become a challenge for (hard) international law to fulfill a shaping function, given that adapting the law to changing circumstances - and ultimately to a changing reality - is limited by various procedural and political factors. In order to create a higher alterability of international law, ${ }^{101}$ the international sphere has developed alternative mechanisms, such as an informalization of international regulation. Both States and other international actors use informal instruments to achieve flexibility, potentially combining an informality of the output and of the actors. Although this comes, for instance, for soft law with a trade-off relating to the binding effect of the norms, it fosters the shaping function of international law as it is broadly understood. ${ }^{102}$

\footnotetext{
${ }^{93}$ See Upendra Baxi, What May the "Third World" Expect from International Law?, 27 THIRD WORLD Q. 713 (2006) (discussing the hope of better reflecting a strong position of third world states).

${ }^{94}$ Hungdah Chiu, supra note 65, at 246-49 (discussing international law as traditionally conceived by China-as instrument of the state and not as an element of control thereof).

${ }^{95}$ Allott, supra note 4, at 404; see also Ruzicka \& Keating, supra note 40, at 10 (describing this as anarchy, from the perspective of international relations).

${ }^{96}$ Pauwelyn et al., supra note 89 , at 742 .

${ }^{97}$ See, e.g., William Burke-White, Regionalization of International Criminal Law Enforcement: A Preliminary Exploration, 38 TEX. INT'L L.J. 729 (2003) (discussing the regionalization of international criminal law).

${ }^{98}$ Pauwelyn et al., supra note 89 , at 743 (discussing the inflexibility of formal international lawmaking).

${ }^{99} I d$. at 739 (stressing how existing conventions in one area of law make the conclusion of new treaties difficult).

${ }^{100}$ See, e.g., Hersch Lauterpacht, The Function of Law in the International Community 248-50 (1933) (addressing the problem of change in the international sphere .

${ }^{101}$ See Niklas Luhmann, The Differentiation of Society 94 (Stephen Holmes \& Charles Larmore trans., Colum. Univ. Press 1982) (discussing alterability as a main characteristic of law).

${ }^{102}$ See, e.g., Jan Klabbers, The Redundancy of Soft Law, 65 NORDIC J. INT'L L. 167, 181 (1996) (discussing the discussion about "binding or less binding" legal norms).
} 
It can also be more difficult for actors in the international sphere to agree on certain guiding principles for the shaping function of law. For instance, considerations of common good often serve as a guiding principle in domestic legal orders. The concept of common interests is, however, less present on the international level. ${ }^{103}$ Although there have been developments towards integrating collective interests into international law, ${ }^{104}$ individual State interests still seem to be a major factor, and currently even seem to gain traction. This influences the shaping function of international law. Consent-based lawmaking becomes more difficult when there is-despite the rhetoric - no meaningful agreement that lawmaking should generally be guided by considerations of common good, trumping particular interests. Along these lines, some hold the opinion that international law cannot fulfill its "true" functions until there is "an international social system capable of processing conflicting interests and conflicting ideas..." ${ }^{105}$ Some even go a step further by understanding the orientation towards the common good not only as one aspect of the potential shaping function of law, but also as an essential requirement of the rule of law. ${ }^{106}$ Even without going that far, at the very least, guiding principles strengthen the shaping function of law. If these guiding principles are less prominent, the potential shaping function can develop with only some difficulty.

Although collective interests as guiding principles might be less pronounced in the context of lawmaking, it seems to play a bigger role when international law is applied. To an extent, international courts and tribunals have attempted to emphasize collective interests as guiding principle. As actors that are neutral vis-à-vis the process of formal law-creation, they are in principle well situated to shape the law from a more holistic point of view because they are less confined by particular interests than States or other actors. This might be one of the reasons for the strong role of some courts in the international sphere, such as the Inter-American Court of Human Rights, or the European Court of Human Rights. Other courts, however, are facing more criticism with regard to a (perceived) particular interests driven approach, such as the International Criminal Court. The existence or non-existence of guiding principles as element of the shaping function of law thus might have a considerable impact on the long-term effectiveness of international adjudication.

\section{Challenges to the System-Related Functions}

The idea of international law fulfilling a system-related function seems to face more conceptual challenges than the content-related functions. Looking at international law through the lens of the legal order has been criticized by some for being too formalistic or positivistic. ${ }^{107}$ If one takes this approach, the extent to which international law has system-related effects or functions does not matter. The focus is instead on actors, power structures, and other concerns of that nature. For those who consider the (additional) lens of the legal order to be analytically and normatively useful, however, the question arises as to what extent international law has an ordering effect or function. ${ }^{108}$

\footnotetext{
${ }^{103}$ Allott, supra note 4 , at 404 .

${ }^{104}$ Bruno Simma, From Bilateralism to Community Interest in International Law, 250 COLleCted COURSES OF THE HAGUE ACAD. INT'L L. 217 (1994); Benedict Kingsbury \& Megan Donaldson, From Bilateralism to Publicness in International Law, in From Bilateralism to Community Interest: Essays in Honour of Judge Bruno Simma 79, 81 (Ulrich Fastenrath et al. eds., 2011).

${ }^{105}$ Allott, supra note 4 , at 409.

${ }^{106}$ Mortimer Sellers, What Is the Rule of Law and Why Is It So Important?, in Democracy AND RULE OF LAW IN THE European Union: Essays ins Honour of JaAp W. DE ZwaAn 3, 6 (Flora A.N.J. Goudappel \& Ernst M.H. Hirsch Ballin eds., 2016).

${ }^{107}$ Martti Koskenniemi, Between Coordination and Constitution: International Law as a German Discipline, 15 REDESCRIPTIONS 45, 63 (2011) (labeling the lens of legal order as a German academic approach that emphasizes consistency more than other legal orders).

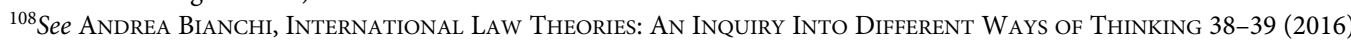
(discussing legal order as a main stream idea).
} 
The conventional perception is that international law as a whole has a weak character of order. Traditionally, the characterization of international law as an order was put forward when it came to delimiting international law to external legal bodies, especially to domestic law. The emphasis has been put on the external dimension of the order, and not as much on the internal structure. International law is seen less as an internally structured entity which is formed by the interrelations of its individual norms, and more as a set of individual provisions which do not necessary communicate and depend on each other. From this perspective, it is understood as an "unsystematic plurality of systems or regimes." ${ }^{109}$ A conceptual unity of international law is regarded as mere chimera. ${ }^{110}$ Accordingly, international law as a whole is perceived to have a less pronounced effect of system-creation.

This perception has various consequences for the interrelations between international legal norms. ${ }^{111}$ One consequence concerns the potential existence of structural principals within international law. If one normatively considers international law to have an overarching function of system-creation, structural principles would be one of the potential instruments fostering such a systematizing effect. Based on the interconnectedness of norms within a group, it is conceptually possible to derive distinct legal principles from the interrelations within this group of norms. For international law, however, such a process would have to overcome a potentially restrictive understanding of the numerus clausus of sources of law. ${ }^{112}$ Tying back every norm to one of the sources listed in Article 38 of the International Court of Justice statute makes it more difficult to argue for overarching structural principles. For example, approaches are criticized which try to create integrative structures of order by developing principles of international administrative law applicable to all international administrative regimes. ${ }^{113}$

As a result - and combined with the increasing fragmentation of international law, ${ }^{114}$ - the ordering function of international law has received a regime-specific orientation. The function of system-creation relates not as much to international law as a whole, but rather to sub-sets of legal norms. Within individual international law regimes such as international criminal law, human rights law, or international trade law, the ordering effect can be strong. Hence, the differentiation of the various international law regimes, sometimes fostered by specific regime-related courts or tribunals, actually strengthens the effect of system-creation on a different scale. Contrary to a conventional reading, the fragmentation of international law can, in this regard, be conceived of as an indicator of the normative ordering function being reinforced.

Inversely, opportunities might arise from the fact that the function of legal system-creation for international law as a "universal whole" is less pronounced. If the inner structures of an order are less strong, the order might be more apt to be open to other groups of legal norms. The external permeability of the order can be potentially greater if the internal structures of interdependence

\footnotetext{
${ }^{109}$ Ralf Michaels \& Joost Pauwelyn, Conflict of Norms or Conflict of Laws?: Different Techniques in the Fragmentation of Public International Law, 22 Duke J. CoMP. \& INT'L L. 349, 375 (2012).

${ }^{110}$ Andreas Fischer-Lescano \& Gunther Teubner, Regime Collisions: The Vain Search for Legal Unity in the Fragmentation of Global Law, 25 Mich. J. InT'L L. 999, 1017 (2004). Mario Prost, The ConCEPT OF Unity in Public InTERnational LaW (2012) (criticizing the narrative discourse of unity).

${ }^{111}$ Koskenniemi, supra note 107, at 63 (criticizing the perception of international law as a system).

${ }^{112}$ See Jean D'Aspremont, Formalism and the Sources of InTernational Law: A Theory of the Ascertainment of LEgAL Rules (2011) (discussing of the formalist understanding of the sources of international law).

${ }^{113}$ See, e.g., Benedict Kingsbury \& Lorenzo Casini, Global Administrative Law: Dimensions of International Organizations Law, 6 INT'L. ORGS. L. REV. 319, 333 (2009) (regarding common procedural principles); see also Administrative Tribunal of the International Labour Organization [ILO] Judgment No. 2991, para. 13 (Feb. 2, 2011) (indicating that international administrative tribunals have started to refer to general principles of international civil service law); World Bank Administrative Tribunal, De Merode et al v. The World Bank, Decision No. 1, para. 28 (June 5, 1981).

${ }^{114}$ Eyal Benvenisti, The Conception of International Law as a Legal System, 50 GERMAN Y.B. INT'L L. 393, 402 (2008); see, e.g., Regime Interaction in International Law: Facing Fragmentation (Margaret A. Young ed., 2012) (discussing fragmentation in general; Anne Peters, Fragmentation and Constitutionalisation, in OXFORD HANDBOOK OF THE THEORY OF INTERNATIONAL LAW 1011 (Anne Orford \& Florian Hoffmann eds., 2016).
} 
between norms are less tight. ${ }^{115}$ As a consequence, there are, for example, some regimes of international law with closer interactions with domestic law than others including: international organizations law; ${ }^{116}$ human rights law; ${ }^{17}$ international investment law; national security law; or, with regard to the need of many of its norms for domestic implementation, international environmental law.

An aspect of the potential system-related function of law that is challenged on the international level is the self-regulation of law. Law is considered to regulate itself based on rules for norm creation and norm application. Internationally, the self-regulating effect of law faces restraints. International norms about norm creation and norm application do of course exist. For example, many treaties have provisions on amending procedures by the parties to the treaty. There is also the Vienna Convention on the Law of Treaties regulating formation and application of treaty law. Even customary international law is confined by rules on norm creation. Yet these formal means of self-regulation have proven to be less efficient in international law than they are, for instance, in many domestic legal orders, as well as in the supranational context. The prevailing, relatively strict formal rules on law-creation are not considered to be flexible enough to meet the needs of international actors. ${ }^{118}$ Consequently, international law-making has developed to reach beyond its own self-regulatory attempts, increasingly using informal processes which are less self-regulated by law. ${ }^{119}$ The application of international law also seems to be less guided by law itself. Given that hard international law, especially treaty law, tends to be created at a specific point in time without much or any subsequent formal modification, ${ }^{120}$ the guidelines for the norm application are limited. The international level is different from the domestic context where legislators regularly can provide a basis for interpretation with every modification made to a statute (and potentially even give explicit reasons for such modifications). As a result, international norminterpreting actors have more leeway. In some treaty frameworks, expert bodies suggest interpretations of legal obligations that amount to establishing new norms. ${ }^{121}$ In others, international courts and tribunals become creative in the further development of old rules and their adaptation to changing factual circumstances. ${ }^{122}$ This is particularly true for treaties with an intended longlasting lifespan such as human rights treaties which are even less likely to be subjected to amendments than other conventions. Although such tendencies by international courts and other actors are increasingly criticized, ${ }^{123}$ they are in a sense embedded into the structure of international law that offers fewer possibilities for the law to regulate its own application. Less self-regulation by law expands the range of actors exercising a norm-creating function through interpretation. ${ }^{124}$

\footnotetext{
${ }^{115}$ See Mattias Wendel, Permeabilität im europäischen Verfassungsrecht (2011) (discussing the concept of permeability of legal orders).

${ }^{116}$ See, e.g., Carol Harlow, Global Administrative Law: The Quest for Principles and Values, 17 EUR. J. INT'L L. 187, 190 (2006) (tying back global administrative law standards to domestic law principles).

${ }^{117}$ See, e.g., Case 6339/05, Evans v. the United Kingdom, Grand Chamber Decision of 10 April 2007, paras. 79, 90 (as an example of the "European consensus" standard in the jurisprudence of the European Court of Human Rights).

${ }^{118}$ Pauwelyn et al., supra note 89 , at 743 . However, other political motivations might have contributed to this development such as e.g. third world approaches which aspired to changing international law making processes, see Bianchi, supra note 108 , at 214 .

${ }^{119}$ Laurence R. Helfer, Nonconsensual International Lawmaking, 2008 UnIV. ILL. L. Rev. 71, 79-90 (2008); see also Pauwelyn et al., supra note 89 , at 743 .

${ }^{120}$ Here again, interpretation provides a mechanism, albeit limited, for development.

${ }^{121}$ See, e.g., U.N. Econ. \& Soc. Council, Comm. No. 15 of the UN Committee on Economic, Social and Cultural Rights on the Right to Water, U.N. Doc. E/C.12/2002/11 (2003), https://www.unhcr.org/en-us/publications/operations/49d095742/ committee-economic-social-cultural-rights-general-comment-15-2002-right.html.

${ }^{122}$ See LAUTERPACHT, supra note 100 , at 254-57.

${ }^{123}$ See The Danish Chairmanship of the Committee of Ministers of the Council of Europe, Draft Copenhagen DeClaration (Feb. 5, 2018) (presenting a recent critique of the jurisprudence of ECHR by member states); see, e.g., Monica Hakimi, Secondary Human Rights Law, 34 YALE J. INT'L L. 596, 599 (2009) (discussing the critique of expert bodies engaging in "aggressive interpretations").

${ }^{124}$ Eckart Klein, Impact of Treaty Bodies on the International Legal Order, in DEVELOPMENTS OF INTERNATIONAL LAW IN TREATY MAKING 571, 575 (Rüdiger Wolfrum \& Volker Röben eds., 2005) (discussing the norm-creating function of expert bodies).
} 
Further, the legal system-creation as a potential function of international law is challenged with regard to the integrative effect that law can have on its addressees. It is increasingly unclear who is actually addressed and bound by international law. Despite decades of discussion about it, many questions have remained without answer: To what extent, if at all, can individuals be considered subjects of international law; are international organizations bound by human rights standards; are corporations bound by international criminal law; or are non-State actors bound by humanitarian law? The appearance of new actors in the international sphere has broadened not only the spectrum of potential addressees, but also the spectrum of uncertainties. Non-governmental organizations, private armed groups, and quasi-executive agencies installed by international organizations are examples that raise the question for the integrative effect of law: To what extent are the defining boundaries of the group of contemporary international law addressees becoming permeable, broadened, or-more skeptically put-indeterminable? ${ }^{125}$

Besides legal system-creation, social system-creation can also be challenged in the international context. Social system-creation relates to the coordinative function of law-law coordinates how to solve problems. For classical international law, this kind of coordination can be difficult in some areas. A considerable amount of the existing problems of international nature are partly or entirely regulated by domestic or transnational law. There are "vast areas of extra-national, non-statal human activity, in particular, vast quantities of economic transactions conducted by industrial, commercial, and financial corporations," which are not coordinated on the international level. ${ }^{126}$ Instead, they are subjected to the "conflicting, overlapping and uncoordinated" domestic legal systems and transnational regimes. ${ }^{127}$ Thus, the space for law to fulfill a problem-solving function in these contexts is, so to say, highly competitive. From the perspective of international law, this space is - at least partially-already taken. What is more, the problem solving takes place in different legal orders, including the international one, but with little or no structured coordination between them. ${ }^{128}$ This effect is multiplied by the fragmentation of international law itself and the little developed coordination between the different regimes. Accordingly, the transnational and multi-level legal structures challenge the coordinative aspect of the system-related function of law. As a reaction, courts have aimed to provide a coordinative effect through the mechanism of judicial dialogue. Courts, however, are restricted both by their position as organs of a particular legal order and by the limitations of case-based judicial law-making. Thus, it is difficult for them to achieve a comprehensive and balanced coordination of the interplay between different legal spaces. If their coordination is not balanced, there is a risk that other international actors will turn to unilateral considerations because they are dissatisfied with unbalanced coordination.

Finally, international and supranational law can have a major effect in terms of political system-creation. Whereas States are characterized by pre-existing political structures, this is much less the case internationally. Of course, power relations between States exist independent of legal regulation, but they are less institutionalized. Law can potentially provide this institutionalization. Accordingly, political system creation is a possible purpose that is of special relevance for law on the international level. Nonetheless, as the example of the EU shows, a strong emphasis on such a function comes with a risk. If the legal dimension remains the predominant one, institutionalization can lack a political counterweight. The created institution might get into disequilibrium. For the EU, the narrative of a "Union based on law" has been increasingly questioned. ${ }^{129}$ This shows that the institutionalizing role of international and supranational law does not have an infinite reach and that the effectiveness of law in this regard can face challenges as well.

\footnotetext{
${ }^{125}$ See, e.g., Daragh Murray, Human Rights Obligations of Non-State Armed Groups (2016).

${ }^{126}$ Allott, supra note 4 , at 404

${ }^{127} \mathrm{Id}$. at 404 .

${ }^{128}$ Whereas the coordination of private law has been attempted by organizations such as the Hague Conference on Private International Law, UNCITRAL, and UNIDROIT, the outcome is still a long way from a harmonized global private law.

${ }^{129}$ See, e.g., Bogdandy, supra note 87, at 519, 527-28; see also Christian Joerges, Recht und Politik in der Krise Europas: Die Wirkungsgeschichte einer verunglückten Konfiguration, 66 MERKUR 1013 (2012).
} 


\section{Challenges to the Power-Related Functions}

The power-related functions of international law have been a particular focus in the discussion about international law and its history. As has been highlighted by various approaches in international law scholarship, the potential function of law to serve as a tool for the exercise of power is extensively visible on the international plane. ${ }^{130}$ International law leaves ample space for power-relations to determine both the content of legal norms and their application. Many scholars have stressed the political character of international law, conceiving international law as a political project. ${ }^{131}$ As has been argued, the autonomy of international law from politics and power structures is less pronounced than that of domestic law. ${ }^{132}$

For international law, this function presents a challenge in itself. Power-relations being reflected in and strengthened by international law are considered to call into question the legitimacy of international law. Current developments such as States criticizing, and withdrawing from, international organizations and courts is but one prominent symptom of that discussion. The assessment of how international law can serve as a tool for exercising power, however, shall not be repeated here. This Article does not focus on how the potential functions themselves can present a challenge for international law. Rather, it aims at discussing how the potential functions are challenged. Accordingly, this Section will concentrate on the potential power-limiting function of international law, which raises the question to what extent it can materialize.

Despite its traditionally horizontal, non-hierarchical character, international law can pursue a power-limiting function. A certain power-limiting effect of international law exists that relates to both the power exercised by international actors in the international sphere and the power exercised by domestic actors in the domestic sphere. ${ }^{133}$ The most obvious element limiting the international exercise of power resides in the international norms guiding and confining political power. Every legal norm obliging an addressee to act in a specific way, or to abstain from a certain action, can be understood as a potential limit to individual power. These norms aim at preventing actors to act exclusively in their respective interest. If one follows this premise, all the international legal provisions creating obligations for States and international organizations can have, in principle, a power-limiting effect. The extent to which this potential effect materializes in practice is a different question. ${ }^{134}$ Beside this general aspect, some international legal norms contain more explicit restrictions of power, such as the norms on the use of force and the acquisition of territory. Under international law, the use of force as one of the elements of power is considered a monopoly of the community. Guaranteeing peace and stability are part of the key objectives of a number of international law regimes. Furthermore, international law aims at limiting not only the individual power of certain international actors, but also their collective power. An example for that are the jus cogens norms that prevent international actors, even in the event of group consensus, to act in a way that would violate a respective jus cogens norm - unless, of course, the international community of States as a whole composes the consenting group. What is more, the international exercise of power can be limited by elements of the separation of power. One of these elements is the creation of international courts and tribunals. ${ }^{135}$ They serve as a framework for the application of

\footnotetext{
${ }^{130}$ These approaches include various critical legal scholars, TWAIL scholars, and Marxist scholars such as David W. Kennedy, A New Stream of International Legal Scholarship, 7 WIS. INT'L L.J. 1 (1988); see also Martti Koskenniemi, The Politics of International Law, 1 Eur. J. INT'L L. 4 (1990); B.S. Chimni, An Outline of A Marxist Course on Public International Law, 17 LEIDEN J. INT'L L. 1 (2004); ANGHIE, supra note 83.

${ }^{131} \mathrm{See}$, e.g., Kennedy, supra note 130 , at 1,7 .

${ }^{132}$ See Cerar, supra note 48 , at 36.

${ }^{133}$ Philip Allott, Eunomia: New Order For A New World 304 (2001) (criticizing the concept of "conceiving of international law as the self-limiting of equal sovereigns").

${ }^{134}$ See Jack L. Goldsmith \& Eric A. Posner, The Limits of International Law (2006) (presenting a skeptical view of whether international law can in fact restrain the interest based relations between states); but see JENS DAvID OHLIN, THE AsSAUlt ON INTERNATIONAL LAW (2015) (criticizing this approach).

${ }^{135}$ Christoph Möllers, The Three Branches: A Comparative Model of Separation of Powers 189 (2013).
} 
international law and can contribute to providing certainty and predictability of the exercise of political power.

International law can also restrain the domestic exercise of power by States. International human rights law is the most prominent field of international law which has a power-limiting function. The various human rights instruments and, where it exists, the related international judicial control aim at confining the exercise of power by States with regard to individuals. In particular, they aim at offering an international layer of confinement in cases where the power-limiting effect of domestic law might be considered insufficient. Here, the interconnection between legal orders and the law's respective functions becomes apparent; international law can fulfill a power-limiting function that shows its effect not only on the international level, but also on the domestic level.

From a normative perspective, international law can have broad or narrow power-limiting functions. A broad function does, however, encounter challenges. In general, an immediate limit to the exercise of power is created by jurisdictio-legal norms controlling other law and binding political power. ${ }^{136}$ What exists internationally in this respect is relatively sparse: It would include jus cogens norms, certain norms contained in the UN Charter, norms in Security Council resolutions, and arguably some norms in human rights law. A fully-fledged hierarchy within the international legal norms does not exist; ${ }^{137}$ the effect of norms formally equipped with primacy over other international law norms is limited. ${ }^{138}$ Instead, the international legal system relies mostly on the indirect power-limiting effect of the institutional structures established by international legal instruments. In this framework, legal relations and power relations are situated on the same level which, in case of conflict, can cause the latter to superimpose the former. The institutional structures established by law aim at counterbalancing such results and at constituting a functional equivalent to an immediate power restriction. Their practical impact is, however, more contingent than an immediate power-limiting effect would be. This can be problematic when, for instance, the international exercise of power intrudes directly into the sphere of the individual. If there are no adequate institutional guaranties, acts of States and international institutions can lack accountability and the exercise of authority can remain unchecked. ${ }^{139}$ In such cases, the power-limiting effect of international law is narrow. From the perspective of other legal orders, a weak power-limiting effect of international law can then be perceived as a shortcoming. It is in these circumstances that other legal orders try to compensate for such a (perceived) shortcoming, be it the European legal order, ${ }^{140}$ or the domestic legal orders. ${ }^{141}$ In this regard, one legal order can serve as jurisdictio for another order. The "Solange" approach of European and domestic courts are an explicit expression of circumstances when a power-limiting function is exercised by an external legal order.

\footnotetext{
${ }^{136}$ See discussion, supra Section B.III. (presenting the term jurisdictio).

${ }^{137}$ See Jure Vidmar, Norm Conflicts and Hierarchy in International Law: Towards a Vertical International Legal System?, in Hierarchy in International Law: The Place of Human Rights 13 (Erica DeWet \& Jure Vidmar eds., 2012) (opining as to the merely limited trumping impact of jus cogens norms on other international law norms).

${ }^{138}$ See, e.g., Rain Liivoja, The Scope of the Supremacy Clause of the United Nations Charter, 57 INT'L CoMP. L.Q. 583 (2008) (discussing the mitigated precedence of the UN Charter over conflicting obligations of the member States).

${ }^{139}$ See, e.g., Benedict Kingsbury, The Administrative Law Frontier in Global Governance, 99 AM. Soc. INT'L L. 143 (2005) (exemplifying the broad accountability discussion); see also Armin Von Bogdandy \& Ingo VenzKe, In Whose Name? A Public Law Theory of International Adjudication 111 et seq (2014) (discussing international public authority).

${ }^{140}$ See, e.g. CJEU, Joint Cases C-402/ 05 P \& C-415/05 P, Kadi \& Al Barakaat, ECLI:EU:C:2008:461, Judgement of 3 September 2008; see also CJEU, Joint Cases C-584/10 P, C-593/10 P \& C-595/10 P, Kadi II, ECLI:EU:C:2013:518, Judgment of 18 July 2013.

${ }^{141}$ A prominent example of this is domestic courts diminishing the broad immunity of international organizations. See, e.g., Siedler (S.M.) v. Union de l'Europe Occidentale, Cours d'Appel de Bruxelles [CA] [Court of Appeals in Brussels] Sept. 17, 2003, Journal des Tribunaux [JT], 2004, 617; Unesco v. Boulois, Tribunal de grande instance de Paris [TGI] [ordinary court of original jurisdiction] Paris, Oct. 20, 1997, Rev. Arb. 575; Cour d'Appel [CA] [regional court of appeal] Paris, 14e ch., June 19, 1998, xxiv Yearbook Commercial Arbitration 294; see also August Reinisch, To What Extent Can and Should National Courts "Fill the Accountability Gap"?, 10 InT'L Orgs. L. Rev. 572 (2014).
} 
Another challenge for a broader power-limiting function of international law is the fact that other than in domestic or even European law, there is no consensus as to what the object for such a limitation of power could or should be. As demonstrated by the various attempts in international law scholarship to conceptualize what the exercise of power in the international sphere actually means and what forms it can take, ${ }^{142}$ power or authority on the international level is even less a monolithic force than it would be domestically. Rather, the exercise of power is complex, multi-layered, and diverse. It emanates from individual States or groups thereof, through international organizations or their agents, in legal or non-legal form, affecting individuals directly or indirectly. Given this plurality of ways to exercise power, the objects of potential limitation are not clearly determined and law thus encounters difficulties in setting limits to all these forms of power.

An additional element of the potential power-limiting function is the certainty and predictability provided by law. With regard to international law, this potential function can face challenges as well. This is in particular due to the aforementioned aspects: Without a sufficient element of control over a determinable set of actors, law cannot provide certainty and predictability to its full effect. Moreover, characteristics such as the voluntarism predominant in the international sphere prevent a general and automatic jurisdiction of international courts and tribunals. Thus, there is no certain judicial control over political power and no certain application of law. This can contribute to creating actual or perceived extra-judicial spaces. Such extrajudicial spaces undermine a potential power-limiting function of law. The non-existence of a system of guaranteed jurisdiction as well as the existing or perceived extra-judicial spaces for certain actions and actors might contribute to other actors questioning existing courts and eluding their jurisdiction. The examples of States rejecting decisions of international courts, tribunals, or arbitral bodies ${ }^{143}$ or withdrawing from their jurisdiction altogether have become numerous. ${ }^{144}$ International organizations can also be placed-or place themselves-in extrajudicial spaces. This is, for instance, the case regarding the question of their liability relating to private law claims advanced by third parties, such as in tort. ${ }^{145}$ In general predictability as to whether the exercise of power by these actors can be legally challenged decreases with the multiplication of new actors in the international arena.

For European Union law, the power-limiting function-at least of supranational law-is more strongly emphasized than for classical international law. This is in particular due to the existing hierarchy between primary and secondary law. European primary law provides for legal norms which are outside of the reach of the political actors within the institutionalized structures of the Union. When the Parliament, Commission, and Council exercise their political power through

\footnotetext{
${ }^{142}$ Possible perspectives on this question include "international public authority" and "global administrative law", see, e.g., The Exercise of Public Authority by International Institutions: Advancing International Institutional Law (Armin von Bogdandy et al. eds., 2010); Benedict Kingsbury \& Richard B. Stewart, Legitimacy and Accountability in Global Regulatory Governance: The Emerging Global Administrative Law and the Design and Operation of Administrative Tribunals of International Organizations, in InTERnational Administrative Tribunals in A Changing World: United Nations Administrative Tribunal Conference: Organized Under the Auspices of the Executive Office of the Secretary-General, New York, Friday, 9 November 2007193 (Katerina Papanikolaou ed., 2008).

${ }^{143}$ See, e.g., Philippines v. China, Case No. 2013-19, Award, (Perm Ct. Arb. 2016) https://pca-cpa.org/wp-content/uploads/ sites/6/2016/07/PH-CN-20160712-Award.pdf (giving rise to China's rejection of this decision; see also Russian Federation Judgement No. 12-П/2016 of April 19, 2016 of the Constitutional Court, https://www.venice.coe.int/webforms/ documents/default.aspx?pdffile=CDL-REF(2016)033-e (rejecting a full-fledged execution of the judgment of the European Court of Human Rights in the case Anchugov and Gladkov v Russia, App Nos. 11157/04 and 15162/05, Decision of 4 July 2013); the decision by the Danish Supreme Court of 6 December 2016, Case No. 15/2014 (setting aside the CJEU judgement of 19 April 2016, Case C-441/14, Dansk Industri).

${ }^{144}$ This includes the withdrawal of Burundi and the Philippines-as well as the attempted withdrawals of South Africa and Gambia-from the International Criminal Court.

${ }^{145} \mathrm{An}$ example of this is the recent litigation against the UN brought on behalf of the cholera victims in Haiti-where a United States Federal Court of Appeals panel upheld the immunity of the UN in an August 18, 2016 decision.
} 
lawmaking, this power is confined by the standards set by the treaties. The respect of these standards is controlled by the Court of Justice of the European Union who has automatic jurisdiction in this regard. Thus, the institutionalized political power within the EU is bound by jurisdictio in the form of European primary law. In addition, the dense intertwinement of Union law and domestic law adds another power-limiting layer. ${ }^{146}$ Indeed, European and domestic law exercise a power-limiting function together. The domestic constitutional law standards are used as an element of power-limitation based on domestic law. ${ }^{147}$ This, however, bears risk as well. The power-limiting function of domestic law can be used as a pretext for achieving political aims. ${ }^{148}$ In such a case, the power-limiting effect would in fact have a power-exercising function. This shows how closely power-limiting and power-exercising functions can be interrelated and how the latter might challenge the former.

\section{Conclusion}

The close scrutiny of the effects and potential functions of law has illustrated three key aspects. First-as mentioned at the outset of this Article- the functions of law offer a yardstick for the effectiveness of legal norms and orders. In this regard, the analysis above has, at its very basis, highlighted that it is important to consider that functions as an analytical yardstick are neither objective nor carved in stone. Being aware of the normative basis of functions as a yardstick enables one to contextualize how international actors, including scholars, assess international law developments, allowing for a more fruitful dialogue on that matter.

Second, this Article has demonstrated that the functions of law provide a differentiated, rather than a uniform standard. Thus, they require a differentiated assessment of the effectiveness of law in different settings. The analysis has shown the details of the functional and conceptual variances of law in different contexts. Linking this back to the current developments in international and supranational law offers an analytical lens to conceptually frame and locate these developments. In this regard, this conclusion advocates for a renewed awareness of the challenges that the potential functions of law encounter in the international and supranational context. This includes an increased sensitization, both on the academic and on the practical level. Understanding the differentiated functionality of law allows for a more adequate analysis of legal phenomena and a more adequate use of legal mechanisms by lawmakers and those who apply the law. What is more, analytically taking into account a differentiated functionality of law can contribute to understanding how the functions of various sets of norms-be it norms labelled as domestic, supranational, international, or transnational law-interrelate and how they might react to each other's particularities.

Last, the function-related analytical lens contributes to providing a broader picture-both for an assessment and a critique of current developments. Instead of examining individual phenomena separately and drawing general conclusions from each of them for international law, the function-related lens of this Article aimed to paint a more encompassing - and at the same time more

\footnotetext{
${ }^{146}$ See Dana Burchardt, Die Rangfrage im europäischen Normenverbund (2015) (discussing this intertwinement and its conceptualization).

${ }^{147}$ See, e.g., Bundesverfassungsgericht [BVerfG] [Federal Constitutional Court] Dec. 15, 2015, 140 ENTSCHEIDUNGEN DES Bundesverfassungsgerichts [BVerfGE] 317; see also Conseil Constitutionnel [CC] [Constitutional Court] decision No. 2006-540 DC, July 272006 (Fr.) (identifying constitutional identity as one element of domestic constitutional law used to limit power); Polish Constitutional Court, decision of 24 November 2010, K 32/09 (same); Ústavní soud České republiky (ÚS), 26.11.2008 [Decision of the Czech Constitutional Court of November 26, 2008] Pl. US. 19/08 (Czech) (same); Corte Cost., 23 novembre 2016, n. 24/2017 (It.) (same); Alkotmánybíróság (AB) [Hungarian Constitutional Court], November 30, 2016, 22/2016. (XII. 5.) (Hung.) (same).

${ }^{148}$ See, e.g., Kriszta Kovács, The Rise of an Ethnocultural Constitutional Identity in the Jurisprudence of the East Central European Courts, 18 German L.J. 1703 (2017); Gábor Halmai, National(ist) Constitutional Identity? Hungary's Road to Abuse Constitutional Pluralism, EUI WORKING PAPER LAW 2017/08.
} 
nuanced-picture. Linking back current developments to a fundamental theoretical categorysuch as the functions of law-enables conclusions about what these developments might mean for the concept of law in general, and for law in specific contexts. Moreover, it allows the assessment of how various developments and phenomena might influence and, importantly, compensate each other. While some phenomena might challenge certain potential functions of law, others might strengthen them. This broader perspective can contribute to offering a more balanced assessment of current legal developments and help to better situate the symptoms of an apparent crisis.

Cite this article: Burchardt D (2019). The Functions of Law and their Challenges: The Differentiated Functionality of International Law. German Law Journal 20, 409-429. https://doi.org/10.1017/glj.2019.29 